\title{
GLOBAL POLITICS: DEMOCRATIC PRACTICE AND THE THREAT LOGIC WITHIN AND BEYOND THE TRANSATLANTIC REGION
}

\section{GLOBÁLNÍ POLITIKA: DEMOKRATICKÁ PRAXE A LOGIKA HROZBY UVNITř A VN'nTRANSATLANTICKÉHO REGIONU}

\author{
Mgr. Getnet TAMENE, PhD. \\ DOC. PhDr. Oōga BOḶÁKOVÁ, PhD. \\ Katedra politológie $\mid$ Department of Political Science \\ Celouniverzitné pracovisko University Department \\ Tren! ianska univerzita A. Dub! eka v Tren! ine Tren! in University of Alexander Dub! ek in Tren! in \\ $\triangle$ Gudentská 2, 91150 Tren! in, Slovak republic \\ E-mail:tameneg@hotmail.com,bocakova@tnuni.sk
}

\begin{abstract}
Annotation
Currently, issues of democratic practice and the threat logic among others have become more discussable themes than ever before in the transatlantic region ${ }^{I}$ and beyond. While the absence of sound common threat has generally deepened the rifts in the relationships of the enlarged transatlantic alliance (ETAA) in the post-CW era, current events have protracted the rifts even further, putting in question the nature of the allianceố democratic practice, which is meant to serve as a model to those beyond it. Since decision making on global issues has been unilaterally dominated by Washington, this behavior significantly discourages democratic practice. It is worth to assess the ETAA in light of democratic practice and global decision making capacity as well as in light of the threat logic. Following the analysis the paper will make a viable recommendation.
\end{abstract}

\section{Key words}

democratic practice, global politics, threat logic

\section{Anotace}

V sú| asnosti, otázky demokratickej praxe a logika hrozby sa nielen v transatlantickom regióne stali oveă viac diskutované témy ako kedyko@̆ek predtým. CieØ̆m príspevku je poukázaŠna to, ǵg zatiaŎ ! o absencia spolo! nej hrozby celkovo prehlbovala trhliny vo vzŠahoch roz ǵrenej transatlantickej aliancie (ETAA), aktuálne udalosti situáciu viac zhorǵsvali, tým ǵf spochybnili demokratickú prax aliancie, ktorá sa pokladá ako vzor pre zvyğgk sveta. KeṆ̆ǵ, v rozhodovaniach o váğhych globálnych otázkach výrazne dominuje Washington, toto správanie významne odrádza demokratickú prax. Bude dôleǵite hodnotiડ̌ ETAA vzhădom na demokratickú prax a z hădiska jej schopnosti rozhodovania o globálnych otázkach ako aj vzhădom na logiku hrozby. V závere príspevku tieǵodporúl ame moǵné rieġenia vzniknutej situácie.

KŎị ové slová

demokratická prax, globálna politika, logika hrozby

\footnotetext{
${ }^{1}$ This refers mainly to the US and Western European countries. In the post-Cold War era it included the Central and Eastern European Countries, which were incorporated to the Atlantic region, while constituting what is now understood as Enlarged Transatlantic Alliance (ETAA). Thus ETAA encompasses a wide array of relations between the two sides of Atlantic, and does not mean NATO per se.
} 
JEL classification: F60

Introduction

Contemporary global issues include vast array of problems ranging from security to global warming, from deepening rifts between the transatlantic region to the relational problems of the regions beyond it, as well as issues of globalization, democratic practice, spying, unilateralism and the like. Inasmuch as the nexus of ETAA to these issues is concerned, recent years have seen some major unpleasant developments in the strategic environment in which ETAA is situated. These include the global financial crisis; multipolarity without multilateralism; technological threats to international ecosystem; evolving rules governing the use of force. These events and sporadically rising social conflicts have dramatic implications on the relationship of post-Cold War transatlantic region, as well as, on its relationship with regions beyond it. This unpleasant development of relationships has dwindled away a united policy making capacity, such as the one, which was predominantly oscillated around the issue of common threat in the bygone era. The results have become in many cases chaotic; since democratic politics based all-inclusive solutions to global issues have not been met yet. Some events of endogenous nature may indicate few positive results, but at exogenous level the trend needs to be carefully seen. This paper tries to analyze in a nut-shell the nature of democratic political practice and developments within the transatlantic region and beyond it.

\section{Democratic political practice in the transatlantic region}

Undoubtedly, the transatlantic region (US\&EU) is a region with the most purposefully democratic governing institutions in history of the human polity. The region is self-conscious about this phenomenon, probably it is also proud of its democratic character, and encourages the rest of the world to emulate its life style. Understanding this conduct will help to identify the policies they adopt (Michalski, 2009), especially towards the regions beyond it, including non-democratic or marginally democratic countries, which it desires to shape in own image.

Though it remains a contested policy proposition, initiatives to assist new democracies and to encourage the emergence of more democracies have been established and have endured on both sides of the Atlantic. The process, however, projects varying approaches. During the two decades straddling the end of the Cold War, Europeans and Americans made it their business to work toward the establishment of democratic governments elsewhere in the world, for reasons ranging from the altruistic and humanitarian to utilitarian or instrumental rationales relating to security and prosperity.

However, as the motives and the approaches become inconsistent, today democracy appears to be backsliding and semi-authoritarian regimes in countries such as China, constitute real alternatives to developing countries in their quest for economic growth and development without having to engage in risky democratic and social reforms. The EU and the US have a shared interest in redeeming the status of democracy promotion. Democracy is part of American and European fundamental values it is also a basic premise of their societies. Furthermore, democracy is a fundamental principle in their foreign policies and becomes an essential aspect of their relations with third countries. Both the US and the EU stand to gain if democracy is reinstated as a concrete expression of fundamental universal value and as a requirement for a multilateral system of governance at a global level. This ideal, however, suffers deficiency and appears to be very distant, mainly, to those beyond the transatlantic region, if it is imposed as a one-way-street. In relation to this, an American NGO Freedom House indicates that more countries have currently seen basic freedoms decline than improve (Freedom in the World, 2009). The inconsistencies, in upholding democratic principles were clear in the past with the US involvement in Latin America and elsewhere; they are observable in various areas currently as well.

It has been also argued that áhe Bush administrationô identification of democracy building with the war in Iraq has discredited the concept both at home and abroadô and that a ǵgeneration of 
work to build consensus at home and legitimacy abroad for USdemocracy promotion is in disarray (Carothers, 2007).

During its EU presidency, in June, officials in the Czech ministry of foreign affairs presented to an international conference meeting in the ministry a policy brief setting forth a ñcommon approachò for the EUQ̂́ ñGlobal pro-Democracy Agenda.ò Europeans and Americans have over the past two generations taken turns in leading the way toward the institutionalization of structures and policies on democracy assistance. In 2009, the EU has stepped forward while the U.S. has stepped back. European and American leaders should work together on the truly large challenges in this realm, while dividing between them the smaller challenges, based on notions of comparative advantage and proximity (Carothers, 2007).

Despite sharing similar value-based foundations and normative principles, cooperation between the EU and the US in the area of democracy has in recent times been neither systematic nor recurrent. The US has in the past been criticized for being an explicit promoter of democracy, adopting a rhetorically charged approach of democracy strategy that too often emphasizes confrontational stances, centers directly on foreign rulers or specific causes and highï lights visible manifestations or symbols of democracy, such as elections (Michalski, 2009). Examples like the case of Iraq War and others underscore the delicate relationship between the articulation of democracy promotion policies that are based on universal values and the pursuit of own interests.

It is also not quite clear in the area of democracy promotion whether the US views the EU as potent treaty based global player. An account of The EUâ efforts to promote democracy shed light on its strengths and weaknesses as well as the challenges ahead (Youngs, 2005). Consequently, the Lisbon Treaty building on the treaties currently in force states unequivocally that the EU must build relations with third countries on the basis of its own values and founding principles, namely ñdemocracy, the rule of law, the universality and indivisibility of human right and fundamental freedoms and respect for human dignityé .ò(Treaty on European Union).

\section{Declining tendencies of post-cold war transatlantic cooperation}

The process of creating the European Union (EU) may be seen as a way for restoring the former prestige and power of diplomacy of the European region. After 1989, however, mainly after the disintegration of the Soviet Union (SU) in 1991, Europe no longer wanted to be a region protected by the US. In the post-CW period, the US has been changed to a hegemon. Europeôs position has changed, too. Its growing ambition for bigger global responsibility could be underlined as one of the major causes of the ever deepening rifts within the ETAA.

All issues of global nature, on which these sides have different opinions, have contributed to generate and aggravate the rifts within and beyond, while hindering the capacity of producing a united policy to address global issues and fostering democratic practice.

Events like the 2003 US led war against Iraq strongly remind us how the ETAA relationships were getting worse, later on, however, after regular elections have brought new faces in governments of both sides of the ETAA, relationships seemed to have been getting somewhat better. Nonetheless, the most current overreaching spy scandals of the US on its allies and others, which came to light following the leaks of various whistleblowers and reporters, have enormously damaged once again an already troubled relationship that has been deeply protracted. ${ }^{2}$ On the other hand, inasmuch as a perception of the ETAA relations with the rest of the world, which may be described as a-one-waystreet, is concerned, much has not changed. It rather reflects the common practice of business as usual,

\footnotetext{
2 The spy scandal has been very worrying. With each leak, as American soft power continued to hemorrhage, hard power has threatened to seep away with it.ò Thus, various News outlets such as The Guardian went on to question what it means ñto be an American ally in the $21^{\text {st }}$ century.ò Also available on: < http://www.theguardian.com/world/2013/oct/23/merkel-nsa-phone-allies-enemies>
} 
where the ETAA humiliates particularly those less developed weaker nations and it easily gets along with it. ${ }^{3}$ None of the ETAA approaches in providing solutions to the current global issues such as world peace conditions, economic progress, ecological or social preferences confirm the relevance of the ETAA trend, as a single effective policy-making choice, to all human polity.

In other words, the ETAA is far from causing unified solutions to array of global issues, indeed, skeptics see it as a kit box for the USô hegemony and its impious imperial lust, which conducts actions that are based on unilateral decisions, such as invasion of nation states, arming and leading armed insurgencies against peoples who want self-determination, drone warfare, economic blockades that harm ordinary people especially children, destabilizing countries, negotiating trade deals that favor US corporations, rendition, black op's, water boarding, spent uranium bombs, increasing poverty, environmental destruction, increasing totalitarian policing and now the bow that ties it all together the security and surveillance state. This exposure is what starts to change an idea about what the US is, and the ETAA that has been constellated around it. None of these phenomenon project genuine democratic practice.

\section{Dwindling significance of the threat logic for the transatlantic future}

As indicated above, the notion of threat has been the linchpin that bound both sides of the transatlantic relationships. It served as a cornerstone for the further existence of the ETAA. The relationships between Europe and the US have been geared to depend on the notion of common threat than anything else over the Cold War period. The threat logic was probably appropriate during that bygone time, but these days it appears to be increasingly out of whack. In the context of security dilemma ${ }^{4}$, sticking to this declining logic of threat does not seem a viable strategy for the ETAA. Consent was very possible during the era of traditional security dilemma (TSD), for instance, over the Cold War period Communism was perceived as an indivisible common threat for all members of the transatlantic partners. In the TSD, the threat logic had served the objective of holding the transatlantic alliance together and to device a unified policy or a workable action plan.

Today, however, with the rise of the new security dilemma (NSD), this threat logic sounds to have been declining. Unlike the TSD, in the case of NSD, the threat logic shows a dwindling trend, mainly, because the threat logic has now become divisible. All members of, for instance, the transatlantic alliance would not be able now to produce a unified common strategy on the grounds of any perceived threats. As the threat logic dwindles so does the transatlantic unison as well. This development has been one result of the shift from TSD to NSD which has taken a faster pace over the post-Cold War era (Cerny, 2000). The shift occurred when the Uni-Multipolar system has replaced the bipolar one during the 1990s. Ever since, the threat logic has become feeble, unable to hold the transatlantic unison.

The following three points belong among the major factors that attempt to explain the falling tendency of the transatlantic relationship. They include:

- The shift from TSD to NSD $і ̈$ this has led the longstanding threat logic to expire;

\footnotetext{
${ }^{3}$ This refers to what is known as the West spearheaded by the US, the euphemism of ófree worldô western dominated global community, international community, or ETAA or the US and its allies, which is using international institutions, military power and economic resources to run the world in ways that may maintain Western predominance in all areas. It has been obvious in various cases including Iraq, Afghanistan, and Libya to show, how it destroys weaker nations and easily gets along with it. Also see Huntington, S. 1993, The Clash of Civilizations, on the next pattern of conflicts. See <http://www.bintjbeil.com/articles/en/d_huntington.html>

${ }^{4}$ Security dilemma refers to the concept that directly and indirectly, both strength and weakness can upset the balance of security in international relations. It is also understood as the spiral model. The term refers to a situation in which actions by a state intended to heighten its security, such as increasing its military strength or making alliances, can lead other states to respond with similar measures, producing increased tensions that create conflict, even when no side really desires it. Also see Cerny, Philip, The New Security Dilemma, pdf.
} 
- The shift from one-way-street transatlantic based nation state politics to the two-way-street that includes those beyond the TAA $\ddot{i}$ this aspect has gathered momentum in the environment of globalization. Since globalization enhances trigger strategies, new actors do inevitably rise, compete and resist one-way-street domination and undemocratic unfair practices;

- The emerging of a $21^{\text {st }}$ Century New Order and pertinent systems $\ddot{i}$ this aspect is currently on motion, it focuses on inducing the rise of a possible human friendly arrangement, which is more just-full towards all the human polity, unlike the one which is currently exhausted and ETAA dominated. The new order and its associated systems are on the rise, the exhausted TAA dominated old order and its associated systems are on the decline. Despite all the attempt of retaining the ETAA dominated old order and its associated system such as unipolarism, chains of events ostensibly confirm the opposite.

The emerging $21^{\text {st }}$ century order may be understood as a World Society Order. The corresponding initial system of this World Society Order is observably the Uni-Multipolar System. This currently observable uni-multipolar system has been tilted towards multipolarism than unipolarism. Thus, one may arguably claim that a multipolar System which presupposes a workable multilateral democracy is on the horizon (Tamene, 2013).

\section{The Transatlantic and those beyond it: the case of Democratic Republic of Congo}

The Democratic Republic of Congo (DRC) is one example among many others to reflect the transatlantic behavior in the face of those beyond it. A number of companies and western governments pressured a United Nations panel to omit details of shady business dealings in a report out in October 2003, concerning the DRC. As the British newspaper, The Independent reported, in October [2002], the panel accused 85 companies of breaching OECD standards through their business activities. Rape, murder, torture and other human rights abuses followed the scramble to exploit Congoô wealth after war exploded in 1998. According to the panel, for example the trade in coltan, a rare mineral used in computers and mobile phones, had social effects ñakin to slaveryò. But no Western government had investigated the companies alleged to have links with such abuses. Some, including ones from the UK, US, Belgium and Germany, had lobbied to have their companiesô names cleared from the ñist of shameò. This is blatantly undemocratic practice that has nothing to do with fostering democracy within those beyond the transatlantic region (International Battle Over Resources), despite ostensible mention of human rights, the rule of law, and democratic practice for all. In the DRC, the conduct of the transatlantic based companies had not confirmed the expected enhancement of peace and democratic practice, in the country; they rather encouraged undemocratic practice that led to further corruption and self-enrichment through exploiting the mineral wealth of the country (Bekoe, Swearingen, 2009). Resources from the mining sector have provided a source of violent competition as well as income for combatants in eastern DRC (Collier, Hoeffler, 2000). Lincény (2012) indicates how media manipulation is able to affect activities in this regard.

\section{Conclusion}

This paper has tried to assess the ETAA in light of democratic practice and global decision making capacity as well as in light of the threat logic. Washingtonôs unilateral decision making approach to global issues significantly discourages democratic practice. Consequently, the logic of finding a unifying common threat that is not just self-serving has now become more difficult between those in the ETAA as well as between the ETAA on one hand and those beyond it on the other. This puts democratic practice based global political decision making capacity at risk, while obstructing perspectives that lead towards cooperative and inclusive end. The most pressing global issues of our time require inclusive global decision making capacity that anchors itself in the practice of genuine democratic politics and on avoiding the dwindling fake logic of threat. The solution this paper recommends envisages a multilateral multipolar arrangement. 


\section{References}

[1] BEKOE, D., SWEARINGEN, M., (2009). What next for the Democratic Republic of Congo? Recommendations from a Trans-Atlantic Diaspora Dialogue. Washington: United States Institute of Peace. Available at: < http://www.usip.org/sites/default/files/resources/drc_diaspora_dialogue.pdf > .

[2] CAROTHERS, T., (2007). Repairing Democracy Promotion, Washington Post.comô Think Tank Town, The Washington Post. [online]. [cit. 2014-1]. Available at: <http://www.washingtonpost.com/wpdyn/content/article/>.

[3] CERNY, P. G., (2000). The New Security Dilemma: divisibility, defection and disorder in the global era. Review of International Studies, vol. 26, iss. 4, pp. 623ï 646. DOI 10.1017/S0260210500006239.

[4] COLLIER, P., HOEFFLER, A., (2000). Greed and Grievance in Civil War. Vol.1. World Bank.

[5] Freedom in the World 2009, (2009). Freedom Retreats for Third Year. [Online]. [cit. 2014-1]. Available at: < http://www.freedomhouse.org/article/freedom-world-2009-freedom-retreats-third-year>.

[6] HUNTINGTON, S., (1993). The Clash of Civilizations, on the next pattern of conflicts. [Online]. [cit. 2014]. Available at: <http://www.bintjbeil.com/articles/en/d_huntington.html>.

[7] International Battle Over Resources. Available at: < http://www.globalissues.org/article/87/thedemocratic-republic-of-congo>.

[8] LINCÉNY, M., (2012). Parliamentary Elections 2012 and Media. In Elections 2012. Tren! ín: Transparent Publisher. pp.138-40.

[9] MICHALSKI, A., (2009). Democracy Promotion in a Transatlantic Perspective: Reflections from an Expert Working Group. Swedish Institute for European Policy Analysis, vol. 2009, iss. 2. ISSN 1651-8942. Available at: < http://www.sieps.se/sites/default/files/518-20092-epa.pdf>.

[10] TAMENE, G., (2013). Alternative Perspectives in International Relations and Politics of the 21st Century. In Journal of Asia Pacific Studies, vol. 3, iss. 1, pp.14-36. ISSN 1944-1096.

[11] Treaty on European Union (as amended by the Lisbon Treaty), art.21. [online]. [cit.2014]. Available at: $<$ http://europa.eu/lisbon_treaty/full_text/index_en.htm>.

[12] What it means ñto be an American ally in the $21^{\text {st }}$ century.ò, (2013). The Guardian, [online]. [cit. 2014]. Available at: < http://www.theguardian.com/world/2013/oct/23/merkel-nsa-phone-allies-enemies>.

[13] YOUNGS, R., (2005). The reluctant debutante: The European Union as promoter of democracy in its neighbor hood. [online]. [cit. 2014-1-2]. Available at: < http://www.fride.org/publication/26/the-reluctantdebutante> 